\title{
PENGARUH BERKUMUR DENGAN LARUTAN TEH HIJAU TERHADAP pH SALIVA PADA SISWA-SISWI SD NEGERI 024761 KECAMATAN BINJAI UTARA TAHUN 2014
}

\author{
Manta Rosma, Netty Jojor Aritonang \\ Jurusan Keperawatan Poltekkes Kemenkes Medan
}

\begin{abstract}
Abstrak
Teh hijau mengandung polyphenol, theofilin, tannin, katekin, serta sejumlah mineral seperti $\mathrm{Zn}$, Se, Mo, fluoride. Kandungan polyphenol dan katekin yang tekandung dalam teh mengurangi plak dan produksi asam oleh bakteri Streptococcus Mutans yang menyebabkan gigi berlubang dan penyakit gusi. Tujuan penelitian ini bertujuan untuk mengetahui pengaruh berkumur dengan larutan teh hijau terhadap $\mathrm{pH}$ saliva pada siswa/i SD Negeri 024761 Kecamatan Binjai Utara Tahun 2014. Jenis penelitian yang digunakan adalah penelitian analitik. Metode yang digunakan quaisi experiment, rancangan dalam penelitian ini adalah pre-test and post-test. Adapun cara pengambilan sampel dengan Purposive Sampling, menggunakan siswa/i kelas V SDN 024761 Kecamatan Binjai Utara sebanyak 30 orang siswa/i, dengan menggunakan test Paper Dental Saliva pH Indikator Untuk mengetahui kriteria asam. Penelitian ini menggunakan uji Wilcon Signed Rank Test Hasil penelitian dikutahui terjadi perubahan kriteria $\mathrm{pH}$ saliva yaitu asam dari $80 \%$ menjadi $0 \%$, netral dari $20 \%$ menjadi $43,33 \%$ dan basa dari $0 \%$ menjadi 56,66\%. Menunjukkan bahwa ada pengaruh berkumur dengan larutan teh hijau terhadap $\mathrm{pH}$ saliva. Hasil uji statistik dengan mengunakan Wilcoxon Signed Rank Test dihasilkan nilai signifikasi 000 (2-tailed) <0,05) maka Ho ditolak dan Ha diterima .Disarankan kepada siswa untuk berkumur menggunakan larutan teh hijau sebagai alternatif tindakan pencegahan terjadinya karies.
\end{abstract}

Kata kunci : Larutan teh hijau, pH Saliva

\section{Latar Belakang}

Kesehatan menurut WHO merupakan keadaan sejahtera secara menyeluruh baik fisik, mental, sosial serta tidak hanya terbatas dari penyakit dan hilangnya kebugaran tubuh. Tujuan pembangunan kesehatan yaitu untuk meningkatkan kesadaran, kemauan, dan kemampuan hidup sehat bagi setiap orang agar terwujud derajat kesehatan masyarakat yang setinggi-tingginya, sebagai investasi bagi pembangunan sumber daya manusia yang produktif secara sosial ekonomi (Depkes, 2009).

Berdasarkan Riset Kesehatan Dasar (RISKESDAS) tahun 2007 diketahui bahwa prevalensi karies aktif pada penduduk Indonesia mencapai 72,1\%. Di pulau jawa persentase penduduk karies aktif tertinggi pada Daerah Istimewa Yogyakarta (DIY) yaitu 52,3\%.Karies gigi merupakan penyakit yang paling banyak dijumpai di rongga mulut bersama-sama dengan penyakit periodontal, sehingga merupakan masalah utama kesehatan gigi dan mulut. Proses karies dan penyakit periodontal disebabkan karena adanya interaksi antara tiga faktor yaitu host (gigi, gingiva, saliva), penjamu (bakteri/plak) dan makanan kariogenik (sukrose).

Beragam manfaat teh tidak lepas dari keberadaan senyawa-senyawa bermanfaat seperti polyphenol, theofilin, tannin, katekin, serta sejumlah mineral seperti $\mathrm{Zn}$, Se, Mo, fluoride, suatu mineral yang dapat mencegah radang gusi dan gigi berlubang. Polyphenol yang tekandung dalam teh mungkin mengurangi plak dan produksi asam oleh bakteri mulut yang menyebabkan gigi berlubang dan penyakit gusi (Christine D. Wu). Berdasarkan hasil penelitian satu cangkir teh hijau sehari sudah cukup untuk menanggulangi gigi keropos bagi anak-anak sekolah hingga 50\%. Bahkan meskipun hanya berkumur saja dengan teh hijau setelah makan merupakan cara yang efektif untuk mencegah gigi kropos. Kadar flouride alami yang terkandung dalam teh hijau sangat efektif mengatasi gigi keropos. Campuran anti bakteri tambahan juga efektif mencegah bakteri yang menyebabkan gigi keropos, streptococcus muttan. Dalam setiap mililiter air ludah dijumpai 10-200 juta bakteri, salah satunya Streptococcus Mutans (Tarigan Rasinta 2013). Bakteri Streptococcus mutans yang berkembang biak akan menyebabkan terbentuknya plak pada lapisan email gigi dan akan menyebabkan derajat keasaman rongga mulut semakin menurun sehingga menyebabkan $\mathrm{pH}$ menjadi asam, sebaliknya berkurangnya bakteri Streptococcus mutans di dalam rongga mulut menyebabkan $\mathrm{pH}$ menjadi basa bahkan bisa menjadi netral. Semakin rendah nilai $\mathrm{pH}$ saliva, makin banyak asam dalam larutan. Sebaliknya meningkatnya nilai $\mathrm{pH}$ saliva berdasarkan latar belakang 
teh hijau yang mengandung senyawa katekin, dimana zat ini berperan menghambat pertumbuhan streptococcus mutans. Bakteri ini mampu menghasilkan asam. Penggunaan air teh seperti yang telah dibuktikan oleh Depkes, yang ternyata juga dapat mengakibatkan remineralisasi lempeng email yang telah di demineralisasi.

Salah satu upaya pencegahan penyakit gigi dan mulut adalah dengan menjaga kebersihan gigi dan mulut agar bakteri tidak tumbuh dan mencegah timbulnya plak lebih lama. Upaya kesehatan gigi pada anak-anak harus dilakukan sedini mungkin, Karena gigi anak-anak usia sekolah dasar mudah terkena karies.Pada umumnya keadaan kebersihan mulut anak lebih jelek dibandingkan dengan orang dewasa karena pola makan anak yang sering makan makanan dan minuman yang bersifat kariogenik. Anak usia sekolah dasar memiliki periode gigi bercampur yaitu terdapatnya gigi sulung dan gigi permanen. Pada masa ini diperlukan pencegahan sedini mungkin. Dari Latar belakang, maka peneliti ingin mengetahui pengaruh berkumur dengan larutan teh hijau terhadap $\mathrm{pH}$ saliva pada siswa/i SDN 024761 Kecamatan Binjai Utara.

\section{Tujuan Penelitian}

Penelitian ini bertujuan untuk mengetahui pengaruh berkumur dengan larutan teh hijau terhadap $\mathrm{pH}$ saliva pada siswa/i di SDN 024761 Kecamatan Binjai Utara.

\section{Manfaat Penelitian}

1. Menambah wawasan masyarakat khususnya siswa/i SDN 024761 Kecamatan Binjai Utara mengetahui pengaruh berkumur dengan larutan teh hijau terhadap $\mathrm{pH}$ saliva.

2. Sebagai sumbangan pemikiran untuk pengembangan ilmu pengetahuan tentang kesehatan gigi dan mulut.

3. Menjadi sumber informasi bagi penelitian selanjutnya dan sebagi bahan referensi di perpustakaan Jurusan Keperawatan Gigi Politeknik Kesehatan Kemenkes

\section{Hipotesis}

Ho : Tidak ada pengaruh berkumur dengan larutan teh hijau terhadap $\mathrm{pH}$ saliva.

Ha : Ada pengaruh berkumur dengan dengan larutan teh hijau pH saliva

\section{Jenis dan Desain Penelitian}

Jenis penelitian yang digunakan adalah penelitian analitik. Metode yang digunakan dalam penelitian adalah quaisi eskperimen atau sering disebut dengan eksperimen semu yaitu suatu penelitian dengan adanya suatu perlakuan terhadap kelompok sampel tetapi tidak ada kelompok kontrol (semua sampel mendapat perlakuan). (Notoatmodjo 2005)

Peneliti melakukan penelitian dengan menggunakan pendekatan Cross Sectional yang merupakan penelitian sesaat, dimana pengambilan data variabel pengaruh dan variabel terpengaruh dilakukan pada waktu yang bersamaan. Rancangan dalam penelitian ini menggunakan rancangan pre-test and post-test (Arikuntoro 2006). Didalam desain ini observasi dilakukan sebanyak 2 kali yaitu : $\mathrm{pH}$ saliva diukur sebelum dan sesudah berkumur dengan larutan teh hijau.

Rancangan penelitian ini secara sistematis dapat ditulis sebagai berikut :

O1-------------X---------------O2

Keterangan:

O1 : Mengukur $\mathrm{pH}$ saliva sebelum berkumur larutan teh hijau.

$\mathrm{X}$ : Perlakuan berkumur dengan larutan teh hijau

$\mathrm{O} 2$ : Mengukur $\mathrm{pH}$ saliva setelah berkumur larutan teh hijau

\section{Populasi dan Sampel Penelitian}

Populasi adalah keseluruhan subjek penelitian. Populasi dalam penelitian ini adalah siswa/i SDN 024761 Kecamatan Binjai Utara yang berjumlah 254 orang.

Sampel adalah sebagian atau wakil populasi yang diteliti. Pengambilan sample secara purposive sampling diambil berdasarkan tujuan tertentu. Sampel penelitian adalah siswa kelas $\mathrm{V}$ yang berjumlah 30 orang.

\section{Hasil Penelitian}

Hasil penelitian yang telah dikumpulkan terhadap siswa/i kelas V SDN 024761 Kecamatan Binjai Utara Tahun 2014. Setelah seluruh data terkumpul, membuat analisa data dengan cara membuat tabel distribusi frekuesi untuk masing-masing sampel. Kemudian dilakukan pengolahan data secara statistik, yaitu menggunakan uji statistik Wilcoxon Signed Ranks Test.

Tabel 4.1

Distribusi pH Saliva Sebelum Berkumur Larutan Teh Hijau Pada Siswa/i Kelas V DN 024761Kecamatan Binjai Utara Tahun 2014

\begin{tabular}{ccc}
\hline Kriteria pH saliva & \multicolumn{2}{c}{ Sebelum Berkumur } \\
& Jumlah & Persentase \\
\hline Asam & 24 & $80 \%$ \\
\hline Netral & 6 & $20 \%$ \\
\hline Basa & 0 & $0 \%$ \\
\hline
\end{tabular}

Tabel 1 terlihat bahwa dari penelitian sebelum berkumur larutan teh hijau Frekuensi $\mathrm{pH}$ saliva terbesar adalah kriteria asam dengan persentase 24 orang (80\%), kemudian netral dengan persentase 6 (20\%). Sedangkan Frekuensi $\mathrm{pH}$ saliva paling sedikit adalah basa dengan persentase 0 orang $(0 \%)$. 


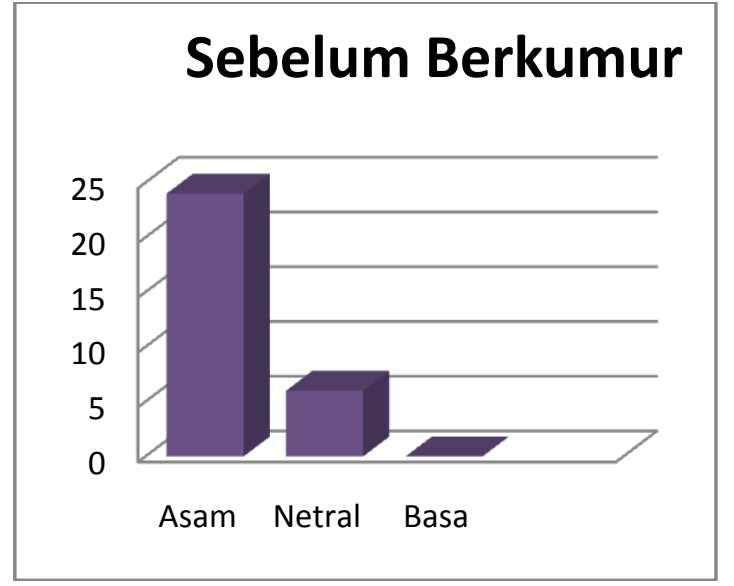

Grafik 5.1 Distribusi Frekuensi Berdasarkan jumlah pH saliva sebelum berkumur larutan teh hijau pada sisiwa/i kelas V SDN 024761 Kecamatan Binjai Utara Tahun 2014.

Tabel 4.2

Distribusi pH Saliva Sesudah Berkumur Dengan Larutan Teh Hijau Pada Siswa/I Kelas V SDN 024761 Kecamatan Binjai Utara Tahun 2014.

\begin{tabular}{ccc}
\hline Kriteria pH saliva & \multicolumn{2}{c}{ Sesudah Berkumur } \\
& Jumlah & Pesentase \\
\hline Asam & 0 & $0 \%$ \\
\hline Netral & 13 & $43,33 \%$ \\
\hline Basa & 17 & $56,66 \%$ \\
\hline
\end{tabular}

Tabel 2 terlihat bahwa ,kriteria $\mathrm{pH}$ saliva setelah berkumur dengan larutan teh hijau terjadi penurunan jumlah asam dari 24 orang $(80 \%)$ menjadi 0 orang $(0 \%)$. Kriteria $\mathrm{pH}$ saliva netral terjadi kenaikan dari 6 orang (20\%) menjadi 13 orang $(43,33 \%)$.Kriteria basa dari 0 orang menjadi 17 orang $(56,66 \%)$.

\section{Sesudah Berkumur}

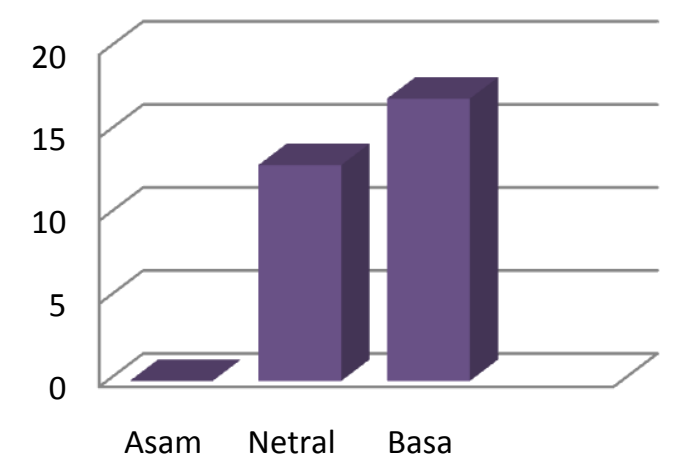

Grafik 5.2 Distribusi frekuensi berdasarkan jumlah $\mathrm{pH}$ saliva sesudah berkumur dengan larutan teh hijau pada siswa/i SDN 024761 Kecamatan Binjai Utara Tahun 2014.

\section{Pengujian Hipotesis}

Pengujian hipotesis penelitian ini menggunakan bantuan program statistika pada komputer menggunakan uji statistik Wilcoxon Signed Rank Test untuk menguji distribusi data.

Tabel 4.3

Uji statistik Wilcoxon Signed Rank Test pH saliva sebelum dan sesudah berkumur dengan larutan teh hijau pada siswa/i SDN 024761 Kecamatan Binjai Utara Tahun 2014

\begin{tabular}{lllll}
\hline & & & $\mathrm{pH}$ & sesudah \\
berkumur & - & $\mathrm{pH}$ & & sebelum \\
berkumur & & & & \\
\hline
\end{tabular}

Asymp. Sig. (2-tailed)

Dari tabel 3. Dapat dilihat bahwa uji statistik Wilcoxon Signed Rank Test nilai signifikasi (2-tailed) 000. Nilai ini $<0,05$, karena nilai signifikasi (2-tailed) $<0,05$ maka Ho ditolak dan Ha di terima.

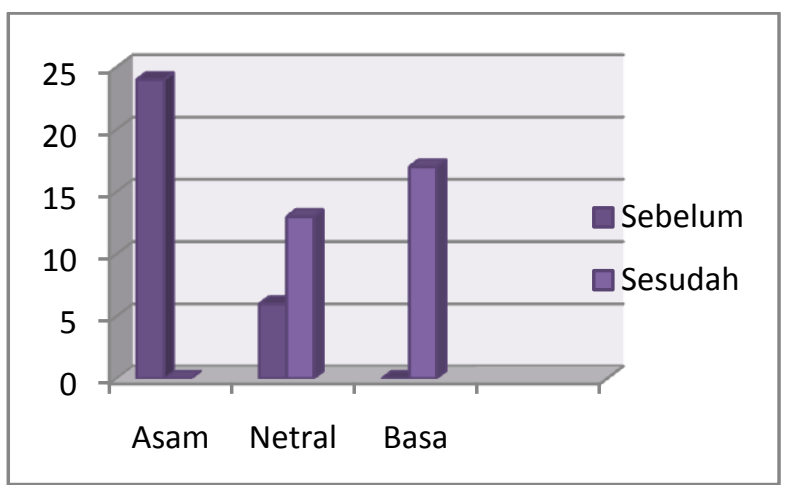

Grafik 5,2 Distribusi frekuensin berdasarkan jumlah $\mathrm{pH}$ saliva sebelum dan sesudah berkumur dengan larutan teh hijau pada siswa/i kelas V SDN 024761 Kecamatan Binjai Utara Tahun 2014. Grafis di atas terlihat bahwa, kriteria $\mathrm{pH}$ setelah berkumur dengan larutan teh hijau terjadi penurunan jumlah asam dari 24 orang $(80 \%)$ menjadi 0 orang $(0 \%)$. Kriteria $\mathrm{pH}$ saliva netral terjadi kenaikan dari 6 orang (20\%) menjadi 13 orang $(43,33 \%)$. Kriteria basa dari 0 orang $(0 \%)$ menjadi 17 orang ( $56,66 \%$ )

\section{Pembahasan}

Hasil penelitian tentang pengaruh berkumur dengan larutan teh hijau terhadap $\mathrm{pH}$ saliva di peroleh data perubahan responden yang memiliki kriteria $\mathrm{pH}$ saliva asam yang mengalami penurunan sebanyak $0 \%$, kriteria $\mathrm{pH}$ saliva netral mengalami peningkatan menjadi $43,33 \%$ dan kriteria $\mathrm{pH}$ saliva basa menglami peningkatan menjadi $56,66 \%$. Dari data tersebut diketahui bahwa dengan berkumur larutan teh hijau tarjadi perubahan kriteria $\mathrm{pH}$ saliva, hal ini dapat terjadi karena berbagai faktor yang terdapat di rongga mulut yang mempengaruhi $\mathrm{pH}$ saliva. Menurur pendapat Amrogen (1991) yang menyatakan bahwa $\mathrm{pH}$ saliva tergantung dari perbandingan asam dan basa. pH saliva dan kapasitas buffer saliva selalu dipengaruhi oleh perubahan - perubahan diantaranya urama siang dan malam, perangsang kecepatan sekresi, 
sifat dan kekuatan rangsangan, diet, kadar hormon dan gerakan mulut. Saliva juga dapat bertindak sebagai buffer menetralkan kembali keadaan asam dan mulut (Afrilina dan Gracinia, 2006) Hal ini sesuai juga dengan penelitian Ajisaka (2012) dengan menyelidiki 36 sampel geraham yang direndam dalam cairan yang berbeda-beda dan di analisa lebih dari 20 minggu hasilnya menunjukkan bahwa teh tidak memiliki efek erosi terhadap lapisan gigi. Para ahli tersebut menganjurkan bahwa meminum teh hijau per hari dapat mencegah pengikisan lapisan email gigi dan kesehtan gigi tetap terjaga.

Hasil pengolahan statistik pada penelitian ini, menggunakan uji Wilcixon Signed Ranks Test menunjukkan hasil signifikasi dari analisa pada data $\mathrm{pH}$ saliva sebelum dan sesudah berkumur dengan larutan teh hijau diperoleh nilai signifikasi (2-tailed $000<0,05)$. Diketahui hipotesis penelitian bahwa, hipotesa nol (Ho) ditolak dan hipotesa alternatif (Ha) diterima. Yang berarti ada pengaruh berkumur dengan larutan teh hijau terhadap pH saliva pada siswa/i SDN kelas V SDN 024761 Kecamatan Binjai Utara tahun 2014. Saliva membantu pertahanan email terhadap asam dengan cara menarik ion flouride dan kalsium kedalam email (Afrilina dan Gracinia,2006). Pendapat Pratiwi (2007) saliva berfungsi sebagai pembersih dalam mulut sehingga dibutuhkan dalam jumlah yang cukup, tetapi kekurangan saliva akan membuat tingginya jumlah plak dalam mulut. Tingkat keasaman saliva juga berpengaruh terhadap timbulnya karies pada gigi, emakin asam suatu $\mathrm{pH}$ saliva seseorang maka,semakin mudah terkena karies (Pratiwi, 2007). Pada umumnya, normal $\mathrm{pH}$ saliva sedikit asam yaitu 6,5. $\mathrm{pH}$ saliva totalnya yang tidak dirangsang biasanya agak asam, bervariasi dari 6,4 sampai 6,9. $\mathrm{pH}$ saliva setelah berkumur cendrung menjadi basa, sehingga terjadi kenaikan dengan kriteria basa. $\mathrm{pH}$ saliva bergantung pada kecepatan sekresi, dan kecepata sekresi dipengaruhi oleh sifat rangsangan. Kenaikan $\mathrm{pH}$ saliva setelah berkumur dikarenakan rangsangan kimiawi dan mekanis yang didapatkan saat berkumur dengan teh hijau.

\section{Simpulan}

Berdasarkan dari hasil penelitian Pengaruh Berkumur dengan Larutan Teh Hijau terhadap pH saliva Pada Siswa/i kelas V SDN 024761 Kecamatan Binjai Utara dapat diuraikan sebagai berikut :

1. Frekuensi $\mathrm{pH}$ saliva terbesar sebelum berkumur dengan larutan teh hijau adalah kriteria asam dengan jumlah persentase $80 \%$.

2. Frekuensi $\mathrm{pH}$ saliva terbesar sesudah berkumur dengan larutan teh hijau adalah kriteria basa dengan jumlah persentase $56,66 \%$.

3. Dari hasil uji statistik Wilcoxon Signed Rank Test diperoleh nilai signifikasi 0,00 karena (2-tailed) $<0,05$ berarti terdapat pengaruh berkumur dengan larutan teh hijau terhadap $\mathrm{pH}$ saliva cendrung kriteria basa.

\section{Saran}

Berkaitan dengan hasil penelitian diatas, maka peneliti memberikan saran sebagai berikut :
1. Bagi siswa/i kelas V SDN 024761 Kecamatan Binjai Utara untuk berkumur dengan obat kumur yaitu menggunakan larutan teh hijau yang berfungsi untuk menetralkan atau meningkatkan $\mathrm{pH}$ saliva sehingga menghambat proses gigi berlubang. Berkumur dilakukan sebanyak 2 kali sehari selama 30 detik.

2. Diharapkan agar hasil penelitian ini dapat berguna sebagai bahan informasi untuk penelitian selanjutnya sehingga akan membantu para peneliti lain dalam melakukan penelitian.

Menambah wawasan bagi penulis tentang pengaruh berkumur dengan larutan teh hijau terhadap $\mathrm{pH}$ saliva, sehingga dapat mengaplikasikan pada diri sendiri dan lingkungan akan pentingnya menjaga kesehatan gigi dan mulut, salah satu caranya ialah berkumur dengan larutan teh hijau.

\section{DAFTAR PUSTAKA}

Arikuntoro, S, 2006, Prosedur Penelitian Suatu Pendekatan Praktek, PT RinekaCipta :Jakarta.

Amerogen, A.Van Niew. Ludah dan Kelenjar Ludah Arti bagi Kesehatan Gigi. Gajah Mada University Press: Yogyakarta, 1992

Edwin, A. M. Kidd,1991,Dasar Dasar Karies Penyakit dan Penanggulangannya, EGC : Jakarta.

Fulder, Stephen, Dr. 2004, Khasiat Teh Hijau, PT Prestasi Pustaka raya : Jakarta.

Listiani, Amelia, S.S.Teh untuk Meningkatkan Kesehatan, INTERAKSA :Tangerang.

Notoamodjo, Soekidjo, 2005, Metodologi Penelitian Kesehatan, PT RinekaCipta :Jakarta.

Rossi, Ara, 2010, 1001 The, C.V ANDI OFFSET (PenerbitAndi) : Yogyakarta.

Sundoro, E. Hartini, 2005, Serba-Serbi Ilmu Konservasi Gigi, Penerbit Universitas Indonesia (UI-Press) : Jakarta.

Tarigan, Rasinta Dr, Drg. 2013, Karies Gigi, EGC : Jakarta.

http://www.scribd.com/mobile/doc/51624087

http://www.tanyadok.com/kesehatan/manfaat-teh-bagi-

kesehatan-gigi

http://bahankuliahmu.blogspot.com/2011/08/ pengertiansaliva-fungsi-saliva-danph.html\#sthash.B3JdOXas.dpuf

http://wisnuvegetarianorganic.wordpress.com/2013/12/03/ 5-manfaat-teh-hijau-untuk-kesehatan-mulut-dangigi/

http://www.pengertianahli.com/2013/10/pengertian-sehatmenurut-ahli-who.html

http://grey.litbang.depkes.go.id/gdl.php?mod=browse\&op $=$ read\&id=jkpkbppk-gdl-res-2009-lellyanday3171\&newtheme=gray

http://repository.usu.ac.id/bitstream/123456789/21672/4/C hapter\%20II.pdf

http://potooloodental.blog.com/?p=498 